\title{
Development of Colaborative Learning Model Based on Permen Cilok Media For Strengthening Education Characters of Elementary School Students in Demak District
}

\author{
Nanik Choirijah \\ \{nanikchoir76@gmail.com\} \\ ${ }^{1}$ Faculty of Teaching and education, Universitas Muria Kudus Gondang Manis PO BOX 53 \\ Bae, Kudus, Central Java, Indonesia Phone (+62291) 438229, Fax (+62291)437198
}

\begin{abstract}
Development of Cilok Media Based Collaborative Learning Model for Strengthening Character Education of Demak Elementary School Students. This research aims to strengthen character education in environmental care for elementary school students through collaborative learning models based on Permen Cilok media as teacher innovations in accordance with technological developments especially in the Demak Regency Primary School. The function of the Permen Cilok media makes learning more interesting. In the media there are character values of environmental care that are integrated into the content of the lesson. This research refers to the Research and development approach, which consists of four steps, namely: 1) Preliminary Study; 2) Model development and validation; 3) Field Test; 4) Dissemination and Dissemination. Data collection techniques consist of observation, interviews, questionnaires and documentation. The data sources of this study were students, 6th grade elementary school teachers in Demak district, expert teams and education offices in Sayung District, Demak Regency. Data analysis carried out in this research and development is a quantitative and qualitative data analysis technique consisting of: needs analysis and analysis of validation test results. There is an increase and positive influence on students' attitudes in learning, especially the character of environmental care. It can be seen from the results of observations. Observation and assessment of students conducted. The results of the overall material validation of the three validators amounted to $90.56 \%$. And the results of the validation of the learning media as a whole amounted to $91.5 \%$. While the overall learning model validation was $90.2 \%$. The results of the overall assessment of respondents received an average of 63.52 with included in either category.
\end{abstract}

Keywords: collaborative, character, environment 


\section{PRELIMINARY}

The occurrence of various kinds of disasters that befall mankind in various parts of the world, including in Indonesia prove that the environment at present has experienced a serious threat. In addition, the dirty environment of the house and school shows that children now lack awareness in protecting the environment. Some indicators that show this are the behavior of disposing of garbage everywhere, the separation between organic and inorganic waste, electricity left on during the day, overflowing tap water, plants left to die dry and so on. In addressing these complex environmental problems, explained by Puji Hardati (2015: 4), there should be a shared awareness that the earth's capacity is very limited. Non-renewable resources must be maintained, and those that can be renewed are always restored. These resources must be saved for the benefit of future generations. Development must be done comprehensively to save the environment. One effort that can be done by education practitioners to protect the environment to be sustainable is by instilling an awareness of environmental love in children.

The age of the children in general are still studying at the elementary level, therefore they need to get environmental education. The main reason is that children's development is largely determined by the environment in which they are raised. It is from this environment that children gain experience in shaping their personalities. In accordance with educational reforms, learning for students should not be done only with lectures, but more important is students must have direct learning experience that is doing their own learning activities (Learning by doing), so that children can build their own learning outcomes (contrukstivism). In learning constructivism, knowledge is not a collection of facts from a reality being learned, but a cognitive construction of a child towards an object and experience from the environment (Budiningsih in Hatimah, (2007: 1.25). Knowledge is not an item that can be transferred from one's mind to person etc. If the teacher intends to transfer a concept, idea, and knowledge, the transfer will be interpreted and constructed by the students themselves through their understanding.

In reality, there are still many environmental problems that are not maintained, especially in the school environment. This is due to the low level of student care about the environment. From the results of the analysis of this problem, the root of the problem is their lack of understanding of the importance of protecting the environment early on. Besides the learning models and media used are less effective and creative so that children are less interested in learning. So to improve character education among students of class VI SD N Purwosari 1 and 2 Sayung Demak to be more concerned about the environment carried out a communicative approach with a collaborative learning model based on Permen Cilok media.

Given the importance of character education caring for the environment, it would be good to instill it early on in children. To implement the idea is certainly not easy, because children have different characteristics from adults. Children have unique learning characteristics, which are gradual, in various ways, with groups of friends and through games. One game that the author will use as a medium to foster a passion for environmental love is the Cilok Candy which is an extension of the Interesting Game of Love for the Environment. With this game, environmental education for children is expected to be active and fun.

This research will discuss the strengthening of character education in elementary school students by using the development of collaborative learning models based on Permen Cilok media. 


\section{Method}

This type of research uses research and development methods or often called Research and Development (R\&D) is used if researchers intend to produce certain products, and at the same time test the effectiveness of certain products in the learning process using media. According to Sugiyono (2016: 407), development research is more directed at efforts to produce certain products and then tested their effectiveness so that they are ready for real use in the field. The product developed in this research is the development of learning models based on game learning media in the form of manual and mobile learning. On manual media in the form of Rolled which contains instructions to carry out activities in groups in accordance with learning. Whereas in the form of mobile leraning is a learning application that can be used by students by utilizing cellphones or laptops in order to foster the strengthening of character education care and love the environment. In this study researchers used a development model according to Sugiyono, the Borg and Gall development model (2016: 409). This model consists of ten steps, namely: (1) potential and problems; (2) data collection; (3) product design; (4) design validation; (5) design improvements; (6) product trials; (7) product revisions; (8) trial of use; (9) product revisions; (10) and mass production manufacture. The ten steps are grouped into four groups. Namely: 1. Preliminary stage (needs analysis), 2. Design / design of the model (product), 3. Product testing, and 4. Dissemination.

Sources of data from the study consisted of sources of learning model data needs, expert validation test data and model effectiveness test data obtained from teachers, students and the Department of Education. The instrument used in gathering data was a validity test questionnaire arranged according to a Likert scale (Sugiyono, 2015 :) that was modified with four alternative answers, namely 1 = less, $2=$ enough, $3=$ good, $4=$ very good. Data analysis by determining the highest score and adding up the scores of each validator. Then provide validity values.

Analysis of the data in this study uses quantitative descriptive techniques that illustrate the collaborative learning model based on the cilok candy media. Quantitative data were obtained from product feasibility assessments given to material lecturers, media, teachers and students. Data obtained through questionnaires collected were then analyzed with quantitative statistics.

Table 1. From the results of the above analysis we will obtain the feasibility of the media with the criteria

\begin{tabular}{ll}
\hline Range & Category \\
\hline $85 \%-100 \%$ & Very decent \\
$69 \%-84 \%$ & Decent \\
$53 \%-68 \%$ & Decent enough \\
$37 \%-52 \%$ & not worth it \\
$20 \%--36 \%$ & Not decent \\
\hline
\end{tabular}




\section{RESULTS AND DISCUSSION}

The overall material validation results from the three validators were $90.56 \%$ (Table 2). From the results obtained with predetermined criteria, the conclusion is that the material developed is declared to be very valid and does not need to be revised and is ready to be used for research. The overall validation results from three validators were $91.5 \%$ (Table 3 ). From the results obtained with predetermined criteria, the conclusion is that the learning media used are declared to be very valid and do not need to be revised and are ready to use.

Tabel. 2 Material Expert Validation Results

\begin{tabular}{llcl}
\hline No & Validator & Prosentase & Category \\
\hline 1. & Validator 1 & $100 \%$ & Very Valid \\
2. & Validator 2 & $85,85 \%$ & Very Valid \\
3. & Validator 3 & $85,85 \%$ & Very Valid \\
& Skor Total & $90,56 \%$ & Very Valid \\
\hline
\end{tabular}

Tabel. 3 Media Expert Validation Results

\begin{tabular}{llcl}
\hline No & Validator & Prosentase & Kategori \\
\hline 1. & Validator 1 & $100 \%$ & Very Valid \\
2. & Validator 2 & $86,5 \%$ & Very Valid \\
3. & Validator 3 & $88 \%$ & Very Valid \\
& Skor Total & $91,5 \%$ & Very Valid \\
\hline
\end{tabular}

Based on Table 3 above, the overall learning media validation results were $91.5 \%$. From the results obtained with predetermined criteria, the conclusion is that the collaborative learning model based on the media of cilok candy developed is declared to be very valid and does not need to be revised and is ready for use.

Tabel. 4 Model Expert Validation Results

\begin{tabular}{|c|c|c|c|}
\hline \multirow[t]{2}{*}{ No } & Validator & \multirow{2}{*}{$\begin{array}{l}\text { Prosentase } \\
100 \%\end{array}$} & \multirow{2}{*}{$\begin{array}{c}\text { Category } \\
\text { Very Valid }\end{array}$} \\
\hline & 1. Validator 1 & & \\
\hline & Validator 2 & $84,5 \%$ & Very Valid \\
\hline & 3. Validator 3 & $86 \%$ & Very Valid \\
\hline & Skor Total & $90,2 \%$ & Very Valid \\
\hline
\end{tabular}


Based on Table 4 above, the overall learning model validation results were obtained at $90.2 \%$. From the results obtained with predetermined criteria, the conclusion is that the collaborative learning model based on the media of cilok candy developed is declared to be very valid and does not need to be revised and is ready to use

Analysis of user data or respondents comes from a questionnaire that has been distributed to students include: Student assessment data on aspects of the content of the material that is in the very feasible category by $34.30 \%$ and the proper category by $65.70 \%$. Student assessment data on aspects of media effectiveness in the very feasible category was $74.30 \%$ and the proper category was $25.70 \%$. Student assessment data on the aspect of media display that is in the very feasible category at $8.60 \%$ and the feasible category at $91.40 \%$. The following table evaluates the user.

Tabel. 5 User assessment results

\begin{tabular}{lcc}
\hline $\begin{array}{l}\text { Aspect } \\
\text { Average }\end{array}$ & \multicolumn{2}{c}{ Category } \\
\hline Score & \\
Efektifitas media & 18,5 & Very Good \\
Tampilan Media & 20.2 & Very Good \\
Model & 12,45 & Very Good \\
& & Very Good \\
Skor Total & 63,52 & Very Good \\
\hline
\end{tabular}

Overall respondents' assessment results covering aspects of the content of the material get an average of 18.5 good categories. In the aspect of instructional quality, the average score was 12.35 which was included in the excellent category. In the aspect of media display, the average score of 20.2 is in the good category. In the aspect of media software, the average is 12.47 which is included in both categories. Overall based on the users get a mean of 63.52 by included in either category.

\section{CONCLUSION}

The results of this research and development are in the form of the final product of the collaborative learning model based on the cilok candy media. First, the cilok candy mediabased collaborative learning model that was developed has gone through a validation process from media experts and material experts with the acquisition that the cilok candy media-based collaborative learning model that was developed is valid and is very appropriate to be used as a medium in the learning process. Second, the collaborative learning model based on the media of cilok candy is effectively used in the learning process of 6th grade students to strengthen student character education. The advantages of the cilok candy-based collaborative learning model developed as follows. a) Students learn to deliberate, b). Students learn to 
respect the opinions of others, c). Can develop critical and rational ways of thinking, d). Can foster a sense of cooperation, e). There is a healthy competition. Besides having advantages, this cilok candy media-based collaborative learning model also has shortcomings, namely, a) The opinions and questions of students can deviate from the subject matter, $b$ ). Requires quite a lot of time, $\mathrm{c}$. The existence of personal traits that want to show themselves or vice versa the weak feel inferior and always depend on others, d). The roundness or conclusion of the material is sometimes difficult to achieve. The results of the overall material validation of the three validators amounted to $90.56 \%$. And the results of the validation of the learning media as a whole amounted to $91.5 \%$. While the overall learning model validation was $90.2 \%$. The results of the overall assessment of respondents received an average of 63.52 with included in either category.

\section{ADVICE}

Teachers should provide learning to students who are active, creative, effective and fun and the government should formulate policies concerning the character values of environmental care.

\section{REFERENCES}

Arikunto. (2010). Prosedur Penelitian. Jakarta: Rineka Cipta.

Arsyad, A. (2013). Media Pembelajaran. Jakarta: Rajawali Pers.

Cahyo, A. N. (2013). Panduan Aplikasi Teori-Teori Belajar Mengajar Teraktual dan Terpopuler. Jogjakarta: DIVA Press.

Coleman. (2012, January). Belajar Sambil Bermain (Learning by Games). tersedia [online] https//:www.kompasiana.com/nabupaloh/550d5ef9813311502cb1e2cc/belajarsambil-bermain-learning-by-games. Diunduh 17/06/2019, pukul 09:34 WIB

Hardati, P. (2015). Pendidikan Konservasi. Semarang: Pustaka Utama.

Herlanti, Y. (2019, Juni 26). Download Pembelajaran Kolaborasi. Retrieved from Wordpress.com: Tersedia [online] https://yherlanti.wordpress.com/2011/09/18/Pembelajaran.kolaboratif. Diunduh 26/06/2019, pukul 13:45 WIB

Imas Kurniasih, d. (2017). Pendidikan Karakter Internalisasi dan Metode Pembelajaran di Sekolah. Jogjakarta: Kata Pena.

Sudjoko, d. (2009). Pendidikan Lingkungan Hidup. Jakarta: Universitas Terbuka.

Sugiyono. (2016). Metode Penelitian \& Pengembangan Research and Development. Jogjakarta: Alfabeta.

Sugiyono. (2016). Metode Penelitian Pendidikan ( Pendekatan Kuantitatif, Kualitatif, dan $R \& D)$. Jogjakarta: Alfabeta. 